\title{
Multiple endocrine neoplasia type 1 gene expression is normal in sporadic adrenocortical tumors
}

\author{
O Zwermann ${ }^{1}$, F Beuschlein ${ }^{2}$, P Mora ${ }^{2}$, G Weber $^{4}$, B Allolio ${ }^{3}$ and M Reincke ${ }^{2}$ \\ ${ }^{1}$ Clinic for Endocrinology and Metabolism, University of Mainz, Germany, ${ }^{2}$ Division of Endocrinology, Medical University Clinic II, \\ University of Freiburg, Germany, ${ }^{3}$ Division of Endocrinology, Medical University Clinic, University of Würzburg, Germany and \\ ${ }^{4}$ Department of Molecular Medicine, Karolinska Institute, Stockholm, Sweden \\ (Correspondence should be addressed to M Reincke, Schwerpunkt Endokrinologie, Abteilung Innere Medizin II, Klinikum der Albert-Ludwig-Universität, \\ Hugstetter Strasse 55, 79106 Freiburg, Germany; Email: reincke@med1.ukl.uni-freiburg.de)
}

\begin{abstract}
Multiple endocrine neoplasia type 1 (MEN1) is an autosomal dominant disorder with neoplasia of the anterior pituitary, the parathyroid, the endocrine pancreas and other endocrine tissues including the adrenal cortex. The tumor-suppressor gene causing this disease was identified at the gene locus 11q13. We recently reported that adrenocortical carcinomas frequently show loss of heterozygosity (LOH) of 11q13, but do not contain point mutations within the MEN1-coding region. To investigate whether reduced gene expression (for example by mutations within the MEN1 promoter) may contribute to the tumorigenesis of sporadic adrenocortical tumors, 24 adrenocortical specimen were studied by Northern blot analysis. This series included six adrenocortical carcinomas, four cortisol-producing adenomas, six aldosterone-producing adenomas, three endocrine-inactive adenomas and six normal adrenal glands. The presence of $\mathrm{LOH}$ of $11 \mathrm{q} 13$ was investigated using five polymorphic microsatellite markers (D11S956, PYGM, D11S4939, D11S4946 and D11S987) close to the MEN1 gene. Poly-A mRNA was hybridized with a PCR-generated cDNA probe of the MEN1 gene, a cDNA of the former MEN1 candidate gene phospholipase (PLC) $\beta 3$ and a mouse $\beta$-actin cDNA for normalization. LOH of $11 \mathrm{q} 13$ was detected in five out of six carcinomas and two inactive adenomas, but in none of the hormone-producing adenomas. Compared with normal adrenals (100 $\pm 6.5 \%$, mean \pm s.E.M.) MEN1 mRNA in adrenocortical tumors was expressed in similar amounts (carcinomas $109 \pm 11 \%$, cortisolproducing adenomas $131 \pm 10 \%$, aldosterone-producing adenomas $113 \pm 13 \%$, endocrine-inactive adenomas $111 \pm 2 \%$ ) with the exception of one adrenocortical carcinoma with low MEN1 mRNA expression (66\%). PLC $\beta 3$ mRNA expression showed a variable pattern without reaching significant differences between the groups. We conclude that since mRNA levels were unaltered in the majority of tumors, mutations of the MEN1 gene causing altered gene transcription is unlikely to be a major pathogenic factor of sporadic adrenocortical tumors.
\end{abstract}

European Journal of Endocrinology 142 689-695

\section{Introduction}

Multiple endocrine neoplasia type 1 (MEN1) is an autosomal dominant disorder with neoplasia of the anterior pituitary, the parathyroid, the endocrine pancreas and other endocrine tissues, including the adrenal cortex $(1,2)$. The tumor-suppressor gene causing this disorder was identified recently at gene locus 11q13 flanked by the microsatellite markers PYGM and D11S4936 $(3,4)$. Previous studies revealed involvement of this gene locus in sporadic endocrine tumors, for instance in tumors of the parathyroid gland (5-7), in anterior pituitary adenomas (8-11), endocrine pancreatic tumors (12-14), aldosterone-producing adenomas of the adrenal cortex (15) and sporadic carcinoid tumors of the lung (16).

Molecular mechanisms leading to adrenal neoplasms are still not elucidated in detail. Our intention was to investigate whether the MEN1 gene plays a role in tumorigenesis of sporadic adrenocortical masses like adrenocortical carcinoma, aldosterone- and cortisolproducing adenomas and endocrine-inactive adenomas. We recently discovered loss of heterozygosity ( $\mathrm{LOH})$ of the MEN1 gene locus in all sporadic adrenocortical carcinomas and two out of 24 sporadic adenomas (17). Sequence analysis of these tumors showed no point mutations within the MEN1-coding region. To investigate whether reduced gene expression (for example by mutations of the MEN1 promoter) may contribute to tumorigenesis of sporadic adrenocortical tumors we investigated 24 adrenocortical tissues by Northern blot analysis. In these tumor samples we determined the transcription of the MEN1 gene and the former MEN1 
candidate gene phospholipase $\mathrm{C}$ (PLC) $\beta 3$, which is located close to the MEN1 gene locus (18).

\section{Patients and Methods}

\section{Patients}

We used tissues of six adrenocortical carcinomas, four cortisol-producing adenomas, six aldosterone-producing adenomas, three non-producing adenomas and six normal adrenal glands. All tumor samples were negative for MEN1 gene mutations within the coding region, as reported earlier (17). All patients had given written informed consent. The study protocol was approved by the ethical committee of the University Hospital of Würzburg. The normal adrenal tissues were obtained after organs were removed from brain-dead patients for transplantation. The adrenal glands were snap frozen in liquid nitrogen immediately after excision and then stored at $80^{\circ} \mathrm{C}$ until processing. The diagnoses of the patients were confirmed by clinical and biochemical and morphological data following standard criteria.

\section{RNA extraction}

Poly-A mRNA was extracted from the tissues using a QIAquick mRNA Extraction Kit (Qiagen, Hilden, Germany) following the manufacturer's protocol. The tissues were stored in liquid nitrogen until microdissection and extraction started. The amount of extracted mRNA was measured photometrically and degradation was excluded by electrophoresis on a $1.2 \%$ agarose gel.

\section{Northern blot}

Three micrograms mRNA and an RNA marker (G319 Promega, Madison, WI, USA) were mixed with loading buffer containing formamide and ethidium bromide, heated for $3 \mathrm{~min}$ at $95^{\circ} \mathrm{C}$, chilled on ice and then loaded on a $1.2 \%$ agarose gel containing $6.6 \%$ formaldehyde. Electrophoresis was run for $13 \mathrm{~h}$ at $40 \mathrm{~V}$. Blotting to a nylon membrane (QIAbrane; Qiagen) was performed as an inversed gravity-assisted blot for $20 \mathrm{~h}$ as described elsewhere (19). The mRNA was crosslinked to the membrane by exposure to UV radiation.

\section{Labeling and hybridization}

A 1895 bp fragment of the MEN1 cDNA was amplified using primers $5^{\prime}$-CCGCCACTATTTCCAGGCTCTGCGGGGC$3^{\prime}$ and 5'-GTAGTTCAGAGGCCTTTGCGCTGCCGCTTG$3^{\prime}$, kindly provided by C. Heppner (NIDDK, NIH, Bethesda, MD, USA). As a PLC $\beta 3$ probe, a $4.4 \mathrm{~kb}$ cDNA fragment of PLC $\beta 3$ spanning the entire coding mRNA sequence was used, as published previously (20). The cDNAs were labeled with $\left[\alpha-{ }^{32} \mathrm{P}\right] \mathrm{CTP}$ (Amersham Buchler, Braunschweig, Germany) using a random primed labeling kit (Boehringer, Mannheim, Germany) following the manufacturer's protocol. Unincorporated nucleotides were separated from radiolabeled DNA probes by NucTrap purification columns (Stratagene, Heidelberg, Germany). Labeling was monitored with $5 \mu \mathrm{l}$ of the probes in scintillation fluid in a beta-counter. The blots were pre-hybridized for $1 \mathrm{~h}$ on $68^{\circ} \mathrm{C}$ with $20 \mathrm{ml}$ Quickhyb (Stratagene), hybridized with the labeled cDNA for $1 \mathrm{~h}$ at $68^{\circ} \mathrm{C}$ and washed twice with $1 \times \mathrm{SSC}$ and twice with $0.5 \times \mathrm{SSC}$ (each containing $0.1 \%$ SDS) for $15 \mathrm{~min}$ at $60{ }^{\circ} \mathrm{C}$. Kodak X-omat-DS films were exposed for $5-48 \mathrm{~h}$ at $-80^{\circ} \mathrm{C}$ using intensifying screens. The blots were stripped and rehybridized with a mouse $\beta$ actin cDNA (Stratagene) for standardization. Scanning densitometry of the major signals (MEN1, $2.8 \mathrm{~kb}$; PLC $1.9 \mathrm{~kb})$ of the autoradiographic films was performed with a video camera and a Macintosh PowerMac 7100 computer-based image analysis system using the NIH Image Program (NIMH, NIH, Bethesda, MD, USA). The results were expressed as a percentage of the mean ofthe normal adrenal glands, after normalization for $\beta$-actin expression and after normalization for a control probe on every blot.

\section{DNA extraction and $\mathrm{LOH}$ analysis}

DNA was extracted from tissue and leukocytes using the Qiagen Blood and Cell Culture DNA Kit (Qiagen) following the manufacturer's protocol.

Primers for the polymorphic microsatellite markers D11S956, PYGM and D11S987 were identical to those published previously (21). PCR was performed in a total volume of $100 \mu \mathrm{l}$ containing $30 \mathrm{pmol}$ of each primer, 2.5 U TAQ polymerase (Perkin Elmer, Foster City, USA) and 100-400 ng DNA. The cycler program was as follows: initial denaturation at $95^{\circ} \mathrm{C}$ for $5 \mathrm{~min}, 30$ cycles of $55^{\circ}$ for $1.5 \mathrm{~min}, 72^{\circ} \mathrm{C}$ for $1.5 \mathrm{~min}, 94^{\circ} \mathrm{C}$ for $1.5 \mathrm{~min}$, final extension at $72^{\circ} \mathrm{C}$ for $5 \mathrm{~min}$. Primer sequence for D11S4939 and D11S4946 and PCR conditions were used as published previously (22), with minor modifications. The PCR product was purified with chloroform, dried under vacuum, redissolved in $10 \mu \mathrm{l}$ formamide and $10 \mu \mathrm{I} \mathrm{H}_{2} \mathrm{O}$ and loaded onto a $6 \%$ polyacrylamide gel (Roth, Karlsruhe, Germany). Electrophoresis was performed at $150 \mathrm{~V}$ for $90 \mathrm{~min}$. After staining with ethidium bromide for $10 \mathrm{~min}$ the amplification products were visualized on a UV screen. LOH was determined by comparing tumor DNA with a leukocyte DNA pattern. Reproducible results were obtained after repetition of each experiment at least twice.

\section{Results}

All tumors were informative for at least three markers tested. Five out of six carcinomas showed LOH of the centromeric markers D11S956 and two out of six revealed LOH of PYGM but none showed $\mathrm{LOH}$ of the intragenic markers D11S4939 and D11S4946 or the telomeric D11S987. LOH of D11S956 was detected in 


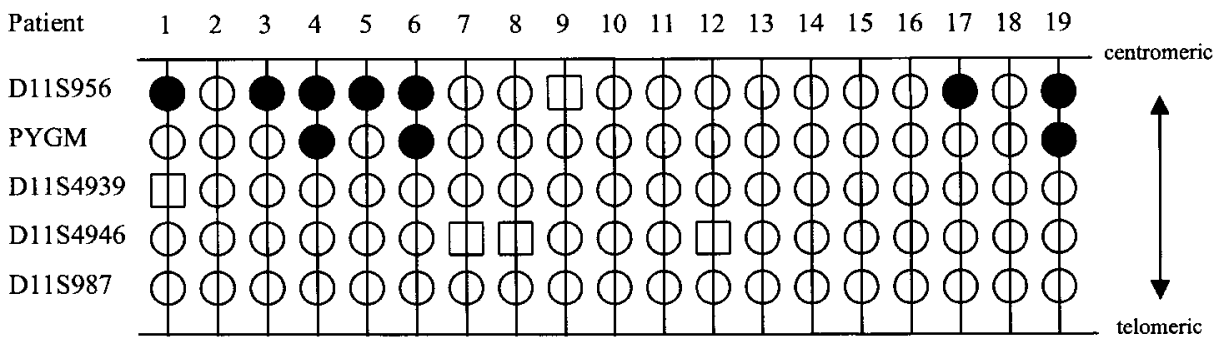

Figure $1 \mathrm{LOH}$ of the five polymorphic markers studied. $O=$ retained heterozygosity, $\bullet=\mathrm{LOH}, \square=$ not informative. Patients $1-$ $6=$ adrenocortical carcinoma, $7-10=$ cortisol-producing adenoma, $11-16=$ aldosterone-producing adenoma, $17-19=$ non-secreting adenoma.

two out of three, and LOH of PYGM in one out of three endocrine-inactive tumors respectively. None of the ten aldosterone- or cortisol-producing tumors showed LOH of any of the markers studied (Fig. 1).

MEN1 mRNA was expressed in roughly equal amounts (70-130\%) in all tumors compared with normal adrenals $(100 \pm 7 \%$, mean \pm s.E.M. $)$ with the exception of one carcinoma with LOH of the MEN1 locus showing a reduced expression of $66 \%$ and two adenomas showing an expression of $157 \%$ and $149 \%$ (Figs 2 and 3 ).

The mean of MEN1 mRNA expression was $109 \pm 11 \%$ for the carcinomas, $131 \pm 10 \%$ for the cortisol-producing adenomas, $113 \pm 13 \%$ for aldosterone-producing adenomas and $111 \pm 3 \%$ for non-producing adenomas compared with normal adrenals.

In contrast to MEN1 mRNA, PLC $\beta 3$ mRNA expression showed greater variability between tumor tissues (Figs 4 and 5). The carcinoma with LOH and decreased MEN1 mRNA levels showed non-detectable PLC $\beta 3$ mRNA expression, whereas the other carcinomas expressed PLC $\beta 3$ mRNA in amounts comparable to normal adrenal glands. Two aldosterone-producing adenomas without LOH of MEN-1 locus and with normal MEN-1 mRNA levels had decreased PLC $\beta 3$ mRNA expression of 51 and 53\% respectively. Cortisoland endocrine-inactive adenomas showed mRNA concentrations comparable to that of normal adrenal tissue.

\section{Discussion}

For nearly a decade since the mapping of the MEN1 locus to $11 \mathrm{q} 13$ and the suggestion that it is a tumorsuppressor gene, efforts have been made to identify the gene responsible for this familial cancer syndrome. Recently, a positional cloning approach led to the identification of the MEN1 gene product, termed menin (3). The predicted 610 amino acid protein structure exhibited no apparent similarities to any previous known proteins. Immunofluorescence studies indicated that menin functions principally as a nuclear protein but may be found in the cytoplasm during cell division $(23,24)$. Further functional approaches revealed the transcription factor JunD as a direct menininteracting partner (25).

Whereas the association of the MEN1 syndrome with adrenal tumors was reported to be a relatively uncommon feature with an incidence of adrenal tumors of 9.6\% (26), other groups found adrenal lesions in 36-40\% of MEN1 patients by computed tomography scan examination $(1,27,28)$. Bilateral adrenal enlargement occurred in $21 \%$ of all patients. Pancreatic endocrine tumors with insulin-proinsulin excess were overrepresented in the
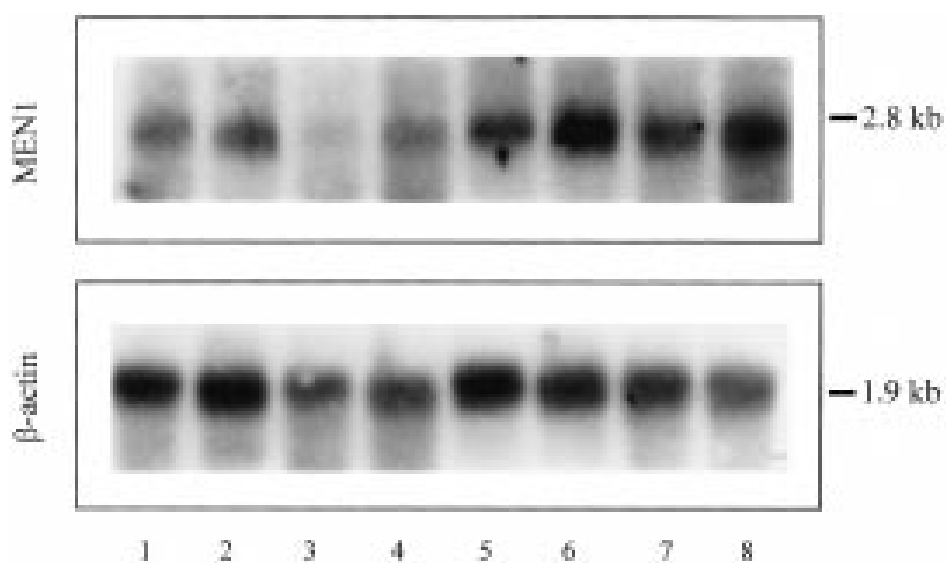

Figure 2 Northern blot after hybridization with MEN1 cDNA with a signal of $2.8 \mathrm{~kb}$ (upper panel) and a mouse $\beta$-actin cDNA for normalization (lower panel). Lanes 1-5 adrenocortical carcinoma, lanes 6-8 cortisol-producing adenoma. One carcinoma shows low MEN1 gene expression (66\% compared with normal adrenal glands). 

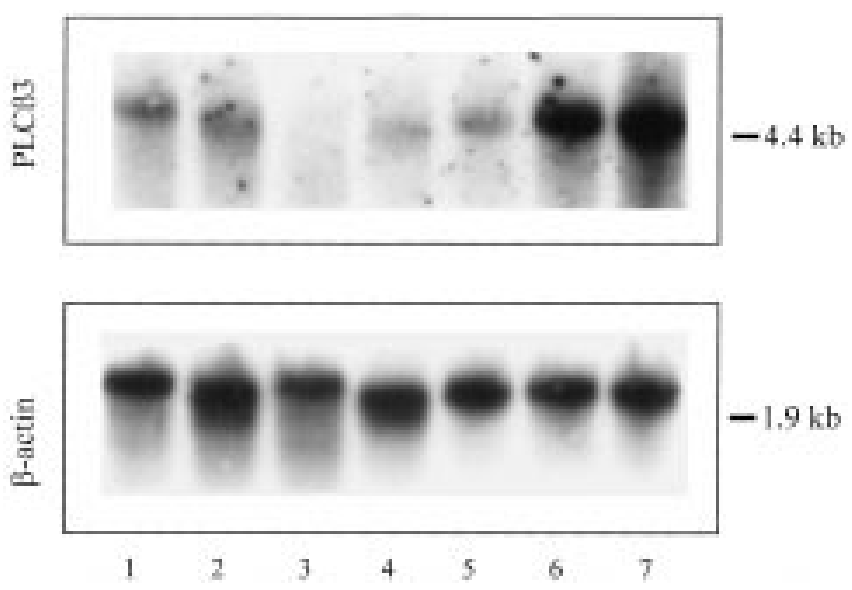

patients with adrenocortical involvement. Histopathology revealed diffuse and nodular cortical hyperplasia, adenomas, and rarely adrenocortical carcinomas (3-6\% of MEN1 patients). The apparently benign adrenal enlargements were not associated with presently ascertainable biochemical disturbances in the hypothalamicpituitary-adrenocortical axis, and they were without radiological signs of progression during follow-up. Whereas in this kindred, only the carcinomas were reported to exhibit adrenocortical hormone excess,
Figure 3 Northern blot after hybridization with PLC $\beta 3$ cDNA with signal at $4.4 \mathrm{~kb}$ (upper panel) and a mouse $\beta$-actin cDNA. Lanes 1-5 adrenocortical carcinoma, lanes 6 and 7 non-secreting adenomas. One carcinoma shows loss of PLC $\beta 3$ expression. occasionally aldosterone-producing adenomas were reported to be coincident with MEN1 (2).

In a recently published manuscript, we investigated 31 sporadic adrenocortical tumors and two adrenocortical tumor cell lines for the presence of mutations of the MEN1 gene locus. LOH was found in five out of five carcinomas and two out of five non-secreting adenomas but no point mutations in the MEN1 gene-coding region could be detected by sequencing of the entire MEN1 gene (17). Kjellman et al. (29) and Görtz et al. (30)

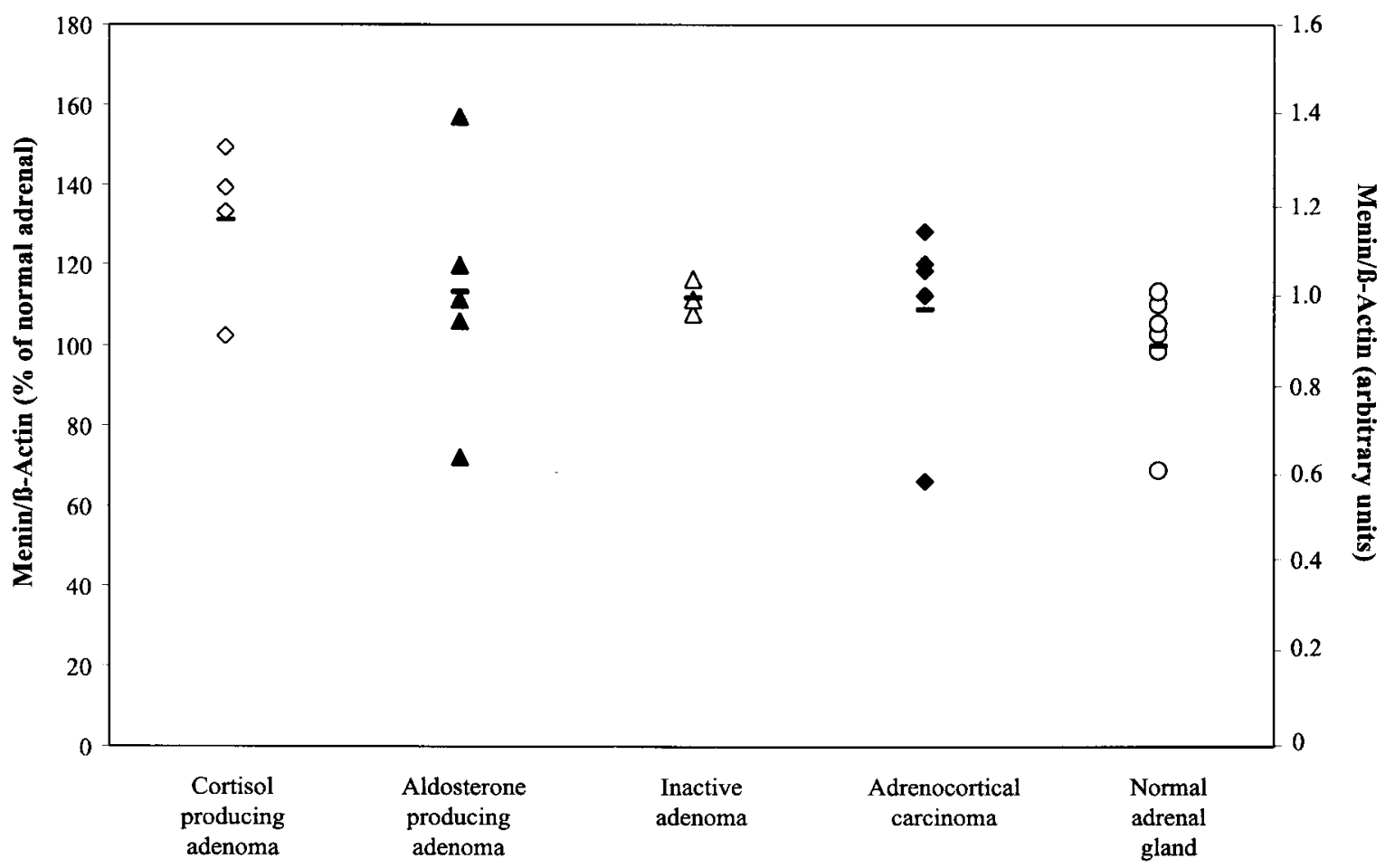

Figure 4 Menin gene expression in the tumors, expressed as menin/ $\beta$-actin ratio (arbitrary units) and compared with normal adrenal glands as $100 \%$. 


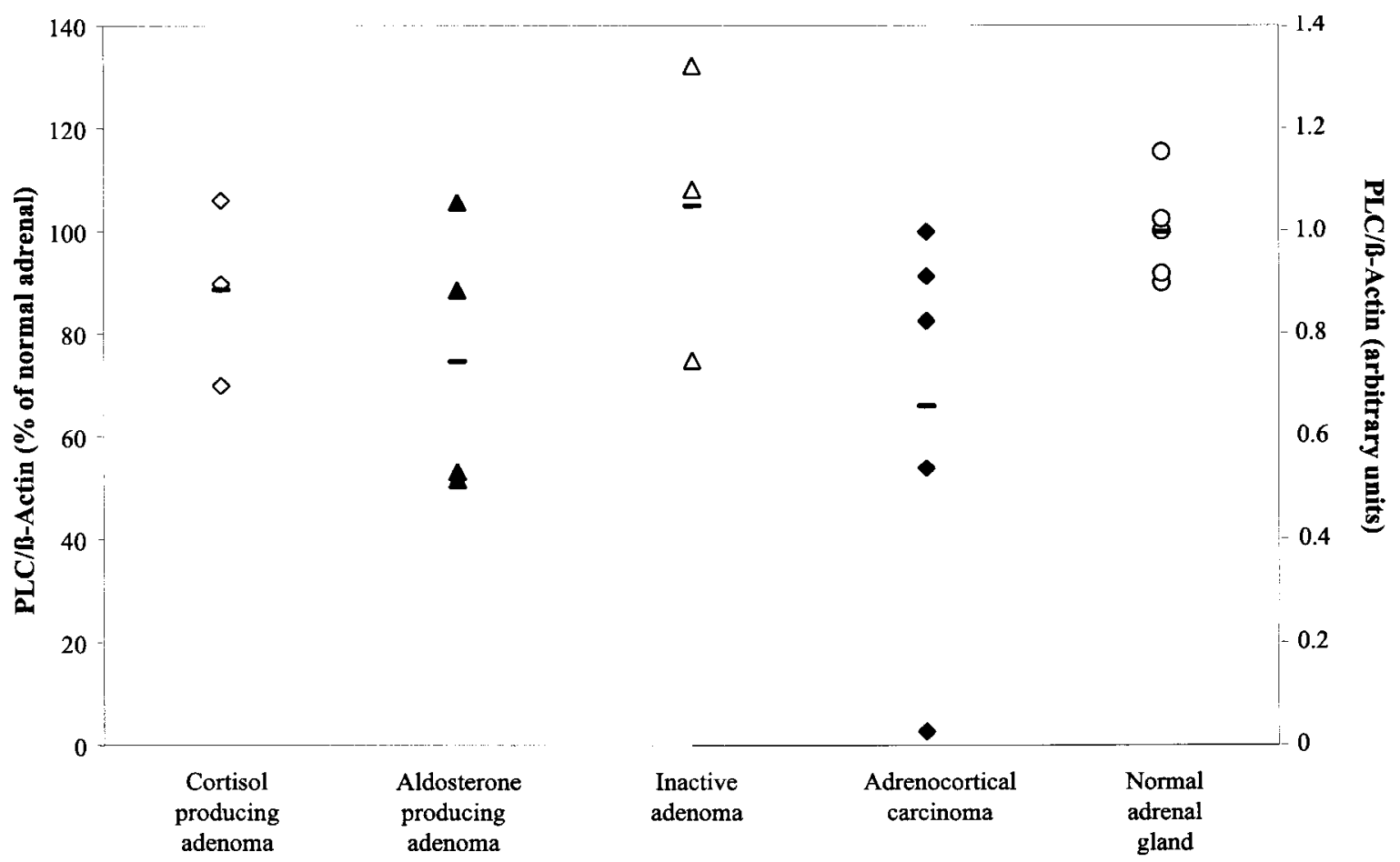

Figure 5 PLC $\beta 3$ gene expression in the tumors, expressed as PLC $\beta 3 / \beta$-actin ratio (arbitrary units) and compared with normal adrenal glands as $100 \%$.

reported similar results with $\mathrm{LOH}$ of the $11 \mathrm{q} 13$ locus in eight out of eight adrenocortical carcinomas and two out of 14 adenomas, and nine out of 29 adrenocortical lesions respectively, but no point mutations in the MEN1 gene.

Nevertheless, if the MEN1 locus is an important tumor-suppressor gene in the adrenal gland, neoplasia may result from decreased gene expression due to epigenetic factors that could result in down-regulation of menin. Possible mechanisms leading to a decrease of MEN1 gene expression could include mutations affecting intronic sequences or the promoter region or splicing sites of the MEN1 gene. In vivo, such mutations have been detected in MEN1 patients by various groups. Therefore we investigated the expression of the MEN1 gene by Northern blot analysis after hybridization with specific cDNA probes.

One carcinoma with $\mathrm{LOH}$ of the flanking marker PYGM showed a slightly decreased MEN1 gene expression of $66 \%$, whereas all other tumors had normal gene expression. Because the MEN1 gene is thought to be a tumor-suppressor gene following Knudson's two-hit model (31), a loss of gene expression of at least $50 \%$ would be expected, but none of our tumors showed loss to that degree, making mutations at the splice sides or in the promoter region unlikely. These data, together with the missing evidence of point mutations within the coding region $(17,29,30)$, suggest that MEN1 gene mutations are not involved in tumorigenesis of sporadic adrenocortical neoplasms, despite the high prevalence of $\mathrm{LOH}$ of $11 \mathrm{q} 13$.

In other sporadic endocrine tumors, mutations in the MEN1 gene are detected more frequently. Hessmann et al. (13) found $\mathrm{LOH}$ in $70 \%$ of malignant tumors of the endocrine pancreas with somatic mutations in three out of the 11 tumors tested. Zhuang et al. (14) detected LOH of $11 \mathrm{q} 13$ in $93 \%$ of sporadic gastrinomas and $50 \%$ of sporadic insulinomas with point mutations of the MEN1 locus in 33 and $17 \%$ respectively. In sporadic parathyroid tumors, LOH was found in 13 out of 45 tumors (6). Six of those tumors harbored mutations in the coding region of the MEN1 gene. Heppner et al. (5) reported $\mathrm{LOH}$ of $11 \mathrm{q} 13$ occurring in 13 out of 33 sporadic parathyroid tumors with mutations of the MEN1 gene in seven of the tumors tested. In sporadic pituitary adenomas, MEN1 mutations were detected less frequently: Tanaka et al. (9) found one case out of 31 pituitary adenomas with LOH of the MEN1 gene locus. This tumor also had a point mutation within the MEN1coding region. Prezant et al. (10) detected one out of 45 adenomas with LOH of 11q13 without a MEN1 mutation, and Zhuang et al. detected four out of 39 tumors with $\mathrm{LOH}$, two of them harboring a point mutation of the other allele (8).

Despite the fact that $\mathrm{LOH}$ of $11 \mathrm{q} 13$ was reported in a series of aldosterone-producing adenomas (15), none of the aldosterone- or cortisol-producing adenomas in our study showed comparable results. Our findings are in 
accord with the results of Kjellman et al. (29) and Görtz et al. (30). Furthermore, Kjellman et al. (32) could not detect genetic alterations at 11q13 with comparative genomic hybridization in sporadic aldosteronomas. Taken together, these data make an involvement of the MEN1 gene in sporadic aldosterone- and cortisolproducing adenomas unlikely.

PLC $\beta 3$ plays an important role in initiating receptormediated signal transduction. Activation of PLC takes place in many cells as a response to stimulation by hormones, growth factors, and other ligands (33). Its functional role together with the mapping of the PLC $\beta 3$ locus to 11q13 made it a candidate gene for MEN1 (34), until further studies excluded mutations in this locus as the cause for tumorigenesis in MEN1 $(35,36)$. However, because of the involvement of PLC $\beta 3$ in signal transduction including the inositol-(1,4,5)-trisphosphate pathway, this gene is not excluded as being a tumorsuppressor gene in general. Loss of expression in a variety of non-familial endocrine tumors was reported for the PLC $\beta 3$ gene. In our series, the polymorphic marker located in the chromosomal region of the PLC $\beta 3$ gene and more centromerically to the MEN1 gene $(18,20)$ showed LOH in five out of six carcinomas and two out of three non-secreting adenomas. Major chromosomal alteration, as observed in adrenocortical carcinomas (29), raises the possibility of involvement of multiple gene loci and possibly different tumor-suppressor genes. Since the 11q13 locus is known to be a genetically unstable region, PLC $\beta 3$ seems to be a secondary event rather than a causative tumor-suppressor gene involved in the tumorigenesis of adrenal cancer. However, there is an increasing body of evidence for the existence of an additional tumor-suppressor gene at $11 \mathrm{q} 13$ based on findings of $\mathrm{LOH}$ of markers localized distally with retained heterozygosity at the MEN1 locus (37-39).

In conclusion, since MEN1 mRNA expression was normal and point mutations are excluded in all tumors tested, we conclude that the MEN1 gene does not play a major role in sporadic adrenocortical tumorigenesis. One carcinoma showed loss of expression of PLC $\beta 3$ mRNA and LOH at 11q13, so PLC $\beta 3$ might need further investigation.

\section{Acknowledgements}

Supported by Dr Mildred-Scheel-Stiftung and the Deutsche Forschungsgemeinschaft (Re 752/11-1).

\section{References}

1 Skogseid B, Larsson C, Lindgren PG, Kvanta E, Rastad J, Theodorsson E et al. Clinical and genetic features of adrenocortical lesions in multiple endocrine neoplasia type 1. Journal of Clinical Endocrinology and Metabolism 199275 76-81.

2 Beckers A, Abs R, Willems P, Van der Auwera B, Kovacs K, Reznik $\mathrm{M}$ et al.. Aldosterone secreting adrenal adenoma as part of multiple endocrine neoplasia type1 (MEN1): loss of heterozygosity for polymorphic chromosome 11 deoxyribonucleic acid markers including the MEN1 locus. Journal of Clinical Endocrinology and Metabolism 199275 564-570.

3 Chandrasekharappa SC, Guru SC, Manickam P, Olufemi SE, Collins FS, Emmert-Buck MR et al. Positional cloning of the gene for multiple endocrine neoplasia-type 1. Science $1997276404-$ 407.

4 Lemmens I, Van de Ven WJ, Kas K, Zhang CX, Giraud S, Wautot V et al. Identification of the multiple endocrine neoplasia type 1 (MEN1) gene. The European Consortium on MEN1. Human Molecular Genetics 19976 1177-1183.

5 Heppner C, Kester MB, Agarwal SK, Debelenko LV, Emmert-Buck MR, Guru SC et al. Somatic mutation of the MEN1 gene in parathyroid tumours. Nature Genetics 199716 375-378.

6 Farnebo F, Teh BT, Dotzenrath C, Wassif WS, Svensson A, White I et al. Differential loss of heterozygosity in familial, sporadic, and uremic hyperparathyroidism. Human Genetics 199799 324-349.

7 Farnebo F, The BT, Kytölä S, Svensson A, Phelan C, Sandelin K et al. Alteration of the MEN1 gene in sporadic parathyroid tumors. Journal of Clinical Endocrinology and Metabolism 199883 26272630.

8 Zhuang Z, Ezzat SZ, Vortmeyer AO, Weil R, Oldfield EH, Park WS et al. Mutations of the MEN1 tumor suppressor gene in pituitary tumors. Cancer Research 199757 5446-5451.

9 Tanaka C. Kimura T, Yang P, Moritani M, Yamaoka T, Yamada S et al. Analysis of loss of heterozygosity on chromosome 11 and infrequent inactivation of the MEN1 gene in sporadic pituitary adenomas. Journal of Clinical Endocrinology and Metabolism 1998 83 2631-2634.

10 Prezant TR, Levine J \& Melmed S. Molecular characterization of the MEN1 tumor suppressor gene in sporadic pituitary tumors. Journal of Clinical Endocrinology and Metabolism $1998831388-$ 1391.

11 Poncin J, Stevenaert A \& Beckers A. Somatic MEN1 gene mutation does not contribute significantly to sporadic pituitary tumorigenesis. European Journal of Endocrinology $1999140573-$ 576.

12 Debelenko LV, Zhuang Z, Emmert-Buck MR, Moritani M, Yamaoka T, Yamada S et al. Allelic deletions on chromosome $11 q 13$ in multiple endocrine neoplasia type 1-associated and sporadic gastrinomas and pancreatic endocrine tumors. Cancer Research 199757 2238-2243.

13 Hessman O, Lindberg D, Skogseid B, Carling T, Hellmann P, Rastad J et al. Mutation of the multiple endocrine neoplasia type 1 gene in nonfamilial, malignant tumors of the endocrine pancreas. Cancer Research $199858377-379$.

14 Zhuang Z, Vortmeyer AO, Pack S, Huang S, Pham TA, Wang C et al. Somatic mutations of the MEN1 tumor suppressor gene in sporadic gastrinomas and insulinomas. Cancer Research 199757 4682-4686.

15 Iida A, Blake K, Tunny T, Klemm S, Stowasser M, Hayward N et al. Allelic losses on chromosome band 11q13 in aldosterone producing adrenal tumors. Genes, Chromosomes and Cancer 1995 $1273-75$.

16 Debelenko L, Brambilla E, Agarwal SK, Swalwell JI, Kester MB, Lubensky IA et al. Identification of MEN1 gene mutations in sporadic carcinoid tumors of the lung. Human Molecular Genetics 19976 2285-2290.

17 Heppner Ch, Reincke M, Agerwal SK, Mora P, Allolio B, Burns AL et al. MEN1 Gene analysis in sporadic adrenocortical neoplasms. Journal of Clinical Endocrinology and Metabolism 199984216 219.

18 Courseaux A, Grosgeorge J, Gaudray P, Pannett AA, Forbes SA, Williamson $\mathrm{C}$ et al. Definition of the minimal MEN1 candidate area based on a $5-\mathrm{Mb}$ integrated map of proximal 11q13. The European Consortium on Men1 (GENEM 1; Groupe d'Etude des Neoplasies Endocriniennes Multiples de type 1). Genomics 1996 37 354-365

19 Koetsier PA, Schorr J \& Doerfler W. A rapid optimized protocol for downward alkaline Southern blotting of DNA. BioTechiques 1993 $15260-262$. 
20 Weber G, Friedman E, Grimmond S, Hayward NK, Phelan C, Skogseid B et al. The phospholipase $\mathrm{C} \beta 3$ gene located at the MEN1 region shows loss of expression in endocrine tumors. Human Molecular Genetics 19943 1775-1781.

21 Larsson C, Calendar A, Grimmond S, Giraud S, Hayward NK, Teh B et al. Molecular tools for presymptomatic testing in multiple endocrine neoplasia type 1. Journal of Internal Medicine 1995238 239-244.

22 Manickam P, Guru SC, Debelenko LV, Agarwal SK, Olufemi SE, Weisemann JM et al. Eighteen new polymorphic markers in the multiple endocrine neoplasia type 1 (MEN1) region. Human Genetics 1997101 102-108.

23 Guru SC, Goldsmith PK, Burns AL, Marx S, Spiegel A, Collins F et al. Menin, the product of the MEN1 gene, is a nuclear protein. Proceedings of the National Academy of Sciences of the USA 199895 1630-1634.

24 Huang SC, Zhuang Z, Weil RJ, Pack S, Wang C, Krutzsch H et al. Nuclear/cytoplasmic localization of the multiple endocrine neoplasia type 1 gene product, menin. Laboratory Investigation $199979301-310$.

25 Agarwal SK, Guru SC, Heppner C, Erdos M, Collins R, Park S et al. Menin interacts with the AP1 transcription factor JunD and represses JunD-activated transcription. Cell 199996 143-152.

26 Chanson P, Cadiot G \& Murat A. Management of patients and subjects at risk for multiple endocrine neoplasia type 1: MEN 1. GENEM 1. Groupe d'Etude des Neoplasies Endocriniennes Multiples de type 1. Hormone Research 199747 211-220.

27 Burgess JR, Harle RA, Tucker P, Parameswaran V, Davies P, Greenaway TM et al. Adrenal lesions in a large kindred with multiple endocrine neoplasia type 1. Archives of Surgery 1996131 699-702.

28 Skogseid B, Rastad J, Gobl A, Larsson C, Backlin K, Juhlin C et al. Adrenal lesion in multiple endocrine neoplasia type 1. Surgery 1995118 1077-1082.

29 Kjellman M, Roshani L, The BT, Kallioniemi OP, Hoog A, Gray S et al. Genotyping of adrenocortical tumors: very frequent deletions of the MEN1 locus in 11q13 and of a 1-centimorgan region in 2p16. Journal of Clinical Endocrinology and Metabolism $199984730-735$

30 Görtz B, Roth J, Speel EJM, Krahenmann A, De Krijger RR,
Matias-Guiu X et al. MEN1 Gene mutation analysis of sporadic adrenocortical lesions. International Journal of Cancer 199980 373-379.

31 Knudson AG. Mutation and cancer: statistical study of retinoblastoma. Proceedings of the National Academy of Sciences of the USA $197168820-823$.

32 Kjellman M, Kalljonieuni OP, Karhu R, Hoog A, Farnebo LO, Auer G et al. Genetic aberrations in adrenocortical tumors detected using comparative genomic hybridization correlate with tumor size and malignancy. Cancer Research 199615 4219-4223.

33 Lagercrantz J, Carson E, Phelan C, Grimmond S, Rosén A, Daré E et al. Genomic organization and complete cDNA sequence of the human phosphoinositide-specific phospholipase $\mathrm{C} \beta 3$ gene (PLCB3). Genomics 199526 467-472.

34 Lagercrantz J, Larsson C, Grimmond S, Skogseid B, Gobl A, Friedman E et al. Candidate genes for multiple endocrine neoplasia type 1. Journal of Internal Medicine 1995238 245-248.

35 Weber G, Grimmond S, Lagercrantz J, Friedman E, Phelan C, Carson $\mathrm{E}$ et al. Exclusion of the phosphoinositide-specific phospholipase $\mathrm{C} \beta 3$ (PLCB3) gene as candidate for multiple endocrine neoplasia type 1. Human Genetics 199799 130-132.

36 de Wit MJ, Landsvater RM, Sinke RJ, Geurts van Kessel A, Lips CJ, Hoppener JW et al. Exclusion of the phosphatidylinositol-specific phospholipase $\mathrm{C} \beta 3$ (PLCB3) gene as candidate for multiple endocrine neoplasia type 1. Human Genetics 199799 133-137.

37 Chakrabarti R, Srivatsan ES, Woods TE, Eubanks PJ, Ebrahimi SA, Gatti RA et al. Deletion mapping of endocrine tumors localizes a second tumor suppressor gene on chromosome 11q13. Genes, Chromosomes and Cancer 199822 130-137.

38 Asa SL, Somers K \& Ezzat S. The MEN-1 Gene is rarely downregulated in pituitary tumors. Journal of Clinical Endocrinology and Metabolism 199883 3210-3212.

39 Farrell WE, Simpson DJ, Bicknell J, Magnay JL, Kyrodimou E, Thakker RV et al. Sequence analysis and transcript expression of the MEN1 gene in sporadic pituitary tumours. British Journal of Cancer $19998044-50$.

Received 11 October 1999

Accepted 22 February 2000 